\title{
Steatitis in wild sharptooth catfish, Clarias gariepinus (Burchell) in the Olifants and Lower Letaba Rivers in the Kruger National Park,
}

\author{
South Africa. \\ K D A Huchzermeyer ${ }^{1 *}$, D Govender ${ }^{2}$, D J Pienaar ${ }^{3}$, A R Deacon ${ }^{4}$ \\ ${ }^{1}$ Sterkspruit Veterinary Clinic, P.O. Box 951, Lydenburg 1120, South Africa, aquavet@telkomsa.net \\ ${ }^{2}$ Scientific Services, South African National Parks, Private Bag X402, Skukuza 1350, South Africa. \\ DPienaar@sanparks.org \\ DannyG@sanparks.org \\ AndrewD@sanparks.org
}

*Corresponding author. Tel. 2713 2354132, fax. 27132353260

E-mail address: aquavet@telkomsa.net

\begin{abstract}
Large numbers of adult Nile crocodiles Crocodylus niloticus (Laurenti) died from pansteatitis during the autumn and winter of 2008 in the lower Letaba and Olifants River gorge in the Kruger National Park, South Africa. Consequently the health status of fish from these waters was investigated. The study presents the pathological findings in fish inhabiting these rivers within the boundaries of the Park. Changes typical of steatitis were diagnosed in many of the larger specimens of sharptooth catfish Clarias gariepinus (Burchell) caught within the Olifants River gorge. These fish carried large amounts of mesenteric fat with characteristic small brown granulomata within the adipose tissue. Necrosis and inflammation of the adipose tissues, with characteristic ceroid accumulation within the resultant granulomata and the associated aggregation of ceroid-containing macrophages, were demonstrated histologically and were typical of steatitis. Other changes included mild thickening
\end{abstract}


and pallor of the gill tissues and swollen, orange, fatty livers. Focal hepatic lipidosis was demonstrated histologically and special stains revealed storage of large amounts of iron in the livers. Blood smears revealed chromatin clumping in erythrocyte nuclei and nuclear and cell membrane irregularities. This is the first record of steatitis in wild caught $C$. gariepinus.

Keywords: Clarias gariepinus, fat, steatitis, crocodiles, Olifants River, Kruger National Park.

\section{Introduction}

Unexplained fish and crocodile deaths in the Olifants River, in the north east of South Africa, have raised concern for a number of years (de Villiers \& Mkwelo 2009). Altered hydrodynamics and extensive industrial, mining and agricultural activities in the catchment in Mpumalanga Province have resulted in this river becoming one of the most threatened aquatic ecosystems in South Africa (de Villiers \& Mkwelo 2009). The Olifants River flows from west to east, for a distance of some $90 \mathrm{~km}$, through the Kruger National Park (KNP) before being joined by the Letaba River in the Olifants Gorge. The gorge extends for a further $9 \mathrm{~km}$ to the Mozambique border where it opens into the Massingir Dam.

The Olifants River gorge and the confluence with the lower Letaba River, are home to one of the most dense populations of large Nile crocodiles Crocodylus niloticus (Laurenti) in South Africa. Large numbers of adult crocodiles were found dead during the autumn and winter of 2008, in both the Olifants and Letaba rivers in an area stretching from about $10 \mathrm{~km}$ upstream of the confluence through the gorge to the 
Mozambique border. Some 180 dead crocodiles out of a known population of at least 600 were found. Other crocodiles showed impaired movement and an inability to swim. Apparently healthy crocodiles as well as those obviously affected were observed in the same area. Autopsies performed on some of the crocodiles by KNP veterinarians revealed exceptionally fat carcasses with an abnormal hardening and yellow discolouration of the fat. Histological examination confirmed an inflammation of the fat typical of pansteatitis (Lane and co-workers, University of Pretoria, personal communication). A further 24 crocodile carcasses were found during the winter of 2009. The Olifants Gorge consists of a steep sided ravine where the Olifants River cuts through the Lebombo Mountains creating a habitat of sandbanks, deep sand bottomed pools and fast flowing rapids. Since the raising of the Massingir Dam wall in Mozambique in 2008 many of the pools and rapids in the gorge have been flooded and clay rich sediments carried by the river have been deposited in the gorge where they have inundated the pools.

The Olifants Gorge lies in a remote area where fish mortalities may go unnoticed, but for the first time, in July 2009, a large fish mortality event was observed within the gorge. Affected fish were almost exclusively large sharptooth catfish Clarias gariepinus (Burchell) and were found in the area in waters overlying the clay rich deposits at the point where the gorge widens into the dam. Fish carcasses were observed to be very fat. The fish kill remained localized in space and time and no mortalities were observed in either the Olifants or Letaba rivers up-stream of the gorge, and fish in Massingir Dam also appeared unaffected. 
Pansteatitis is a nutritionally mediated condition characterized by necrosis and inflammation of the adipose tissues. The condition has been described from many species of both warm and cold-blooded animals, associated with the feeding of rancid or unsaturated fats, often of fish origin, particularly in the absence of sufficient vitamin E (Fytianou, Koutinas, Saridomichelakis \& Koutinas 2006; Goodwin 2006; Herman \& Kircheis 1985; Murai \& Andrews 1974; Roberts, Richards \& Bullock 1979; Roberts \& Agius 2008). Previously described cases of pansteatitis in crocodiles were associated with consumption of large numbers of dead and rancid fish consumed by farmed crocodiles (Huchzermeyer 2003). Larsen, Buergelt, Cardeilhac \& Jacobson (1983) reported steatitis at slaughter in apparently healthy alligators fed an exclusive fish diet. Mass fish mortality, caused by acid mine seepage, was found to be the most likely cause of the deaths of significant numbers of crocodiles and terrapins as a result of pansteatitis in Loskop Dam, higher up on the Olifants River, in 2007 (Myburgh and co-workers, University of Pretoria, personal communication). The 2008 episode of crocodile pansteatitis in the KNP was noteworthy by the absence of observed fish mortality, although circumstantial evidence pointed to illegal fishing activity with gill nets within the gorge as a possible source of dead, rancid fish. This led to extensive sampling and examination of fish from the Olifants and Letaba rivers within the KNP in an attempt to identify precipitating factors that may have contributed to the development of pansteatitis in the crocodiles.

Fish specimens were collected from the Olifants and Letaba Rivers in the KNP on various occasions since the pansteatitis related deaths of crocodiles first became apparent in 2008. This project forms part of the multidisciplinary research into the 
causes of the crocodile mortalities under the auspices of the Consortium for the Restoration of the Olifants Catchment (CROC) initiative.

\section{Materials and methods}

Various species of fish, comprising a total of 115 specimens, were collected from five different localities along the Olifants and Letaba Rivers: Olifants Gorge, from the confluence with the Letaba River (S:2359'32” E:031 $\left.{ }^{\circ} 49^{\prime} 57^{\prime \prime}\right)$ to the Mozambique

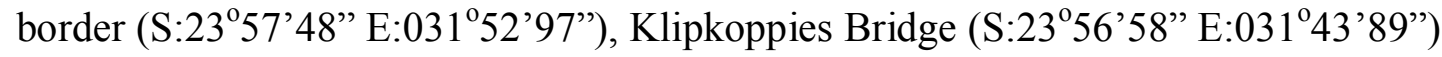
above the cascade on the Letaba River and Ludwich's Hut (S:23 $58^{\prime} 29^{\prime \prime}$ E:031 $\left.{ }^{\circ} 47^{\prime} 41^{\prime \prime}\right)$ below the cascade on the Letaba River, Ngotso (S:24 $02^{\prime} 96^{\prime \prime}$ E:031 $\left.{ }^{\circ} 44^{\prime} 24^{\prime \prime}\right)$ on the Olifants River and at Mamba Weir (S:24 03 '32” E:031 $\left.{ }^{\circ} 14^{\prime} 14^{\prime \prime}\right)$ on the Olifants River near the western boundary of the KNP (Fig. 1). Samplings took place during September 2008, and January, June, July, August and November 2009. Autopsies, blood smears and histological examination were used to determine the degree and variation of pathological changes present in the fish. Initially, a broad range of fish represented in these rivers was examined but sampling was later restricted to $C$. gariepinus.

Baited hook and cast netting were used to catch fish. All the fish were anaesthetized for blood collection using a benzocaine hydrochloride bath at approximately $30 \mathrm{ppm}$ strength prior to being euthanazed. Fish were euthanazed through an over-dose of benzocaine hydrochloride. Blood samples were drawn from the vessels just ventral to the vertebral column, either from the tail region in the case of anaesthetized fish or through the kidney during post mortem dissection of the fish. Fresh blood smears were taken from all fish. Gill wet mounts were examined microscopically for gill 
condition and presence of parasites. Fish were examined by autopsy for gross pathological changes and data sheets were compiled. Data included length and weight measurements, body condition, organ descriptions, level of parasitism and stomach and intestinal content. Samples from a range of organs and tissues were fixed in $10 \%$ buffered formalin for histological examination.

Formalin fixed tissue specimens were processed using standard histological technique and $5 \mu \mathrm{m}$ sections were prepared and stained with haematoxylin eosin (HE). Periodic acid-Schiff (PAS), Gomori's aldehyde fuchsin (GAF) and Perl's Prussian blue stain were used to stain selected sections. Blood smears were stained with a CAM's quick stain (Kyro-Quick stain, Kyron Laboratories). Blood smears and histological sections were examined by standard light microscopy.

\section{Results}

Characteristic of the C. gariepinus specimens collected from the Olifants Gorge and lower Letaba River was the large amount of variably coloured fat in the body cavity and between the muscles of the tail and the distinct white and brown spots observed within the mesenteric fat of some fish. By contrast other species of fish collected had white fat devoid of lesions. In C. gariepinus, fat colour, particularly prominent in the mesenteric fat reserves, varied from almost pure white through shades of cream to yellow. Leaner fish with only small amounts of mesenteric fat invariably had dark yellow to orange fat. Various nodular reactions were observed in the adipose tissues of $C$. gariepinus specimens. Parasitic granulomata were distinguishable from foci of inflammation and granuloma formation associated with non-parasitic causes. Parasitic granulomata in the mesenteric fat of some of the $C$. gariepinus specimens were 
typically well circumscribed and white in appearance, ranging from 2 to $15 \mathrm{~mm}$ in diameter. On incision these revealed a central encysted parasite, and consisted of a well-defined white connective tissue reaction. These parasitic granulomata differed from smaller granulomata of varying shades of brown which when present, were numerous and mostly did not exceed $5 \mathrm{~mm}$ in diameter (Fig. 2A). These granulomata were often focally disseminated throughout the entire mesenteric fat, in severe cases imparting a granular grey brown discolouration, in milder cases appearing to cluster along blood vessels. Advanced granulomata presented with a central, less than $1 \mathrm{~mm}$ in diameter orange area, imparting a granular or rough appearance with a diffuse increase in consistency and in some cases with almost total obliteration of normal fat tissue (Fig. 2B).

The histological appearance of the non-parasitic granulomata in the adipose tissues was typical of lesions expected with steatitis and consisted of varyingly enlarged as well as ruptured adipocytes surrounded by a dense mass of ceroid-containing macrophages (Fig. 3A), with presence of variable numbers of fibroblasts. These lesions were focally disseminated throughout the affected mesenteric adipose tissue and represented the brown granulomata noted macroscopically. Smaller lesions consisted primarily of ceroid-containing macrophage aggregations within the interstitium of the fat tissues. Presence of ceroid in the macrophages was confirmed by staining with GAF (Fig. 3A, B) and PAS stains. Multinucleate Langhans giant cells surrounding an irregular central necrotic area were evident in most of these granulomata (Fig. 3C). These central areas often consisted of an irregular refractile substance, described by Begg, Bruno and McVicar (2000) as lipopigment (Fig. 3A), evident as yellowish, amorphous material in haematoxylin eosin stained smears. 
Similar yellow, granular and refractile inclusions of varying size were present in many of the surrounding macrophages of most lesions (Fig. 3D). In some lesions, more compact macrophages were arranged in the form of an epithelioid type sheath surrounding the ruptured fat cells. Advanced cases presented with a clear lacuna surrounded by organised layers of epithelioid cells that in places coalesced and became embedded in fibrous connective tissue. Granulomata were found primarily in the mesenteric fat reserves and could not be demonstrated in the fat cushion behind the pectoral fin or in the epicardial fat, the hypodermal or intermuscular fat. A distinct exudative peritonitis associated with signs of steatitis was observed in a single $C$. gariepinus specimen that was caught in the gorge on the Mozambique border. Parasitic granulomata of varying sizes were common in the mesenteric, hypodermal and intermuscular fat but were not noted in the pectoral fat.

Brown granulomata in the fat were observed in both male and female fish but were absent in specimens under $2 \mathrm{~kg}$ body mass and measuring $<70 \mathrm{~cm}$ in length. The prevalence of macroscopically characteristic lesions of steatitis on various sampling occasions during 2008 and 2009 is illustrated in Table 1. In the week after the July 2009 fish die-off in the gorge, six C. gariepinus specimens were caught in the area of the fish kill. All these fish showed presence of brown granulomata in the fat. The same granulomata were again observed in 4 out of 12 specimens caught on the Mozambique border during August 2009.

Livers of $C$. gariepinus from the Gorge ranged in colour but appeared distinctly orange, fatty and swollen in appearance compared to fish caught in other sections of the river. A varying degree of fat vacuolation in the livers, often within clearly 
defined zones was characteristic of fish collected from the gorge (Fig. 4A). Large amounts of ceroid, golden brown breakdown products of oxidised unsaturated fat as well as iron or haemosiderin were visible within the hepatocytes. In places, welldemarcated foci of fat vacuolation contained distinctly less iron than in surrounding hepatocytes. In other areas the haemosiderin appeared clumped within the zone of fat vacuolation (Fig. 3B). Adventitious macrophages were numerous in the liver where they contained large deposits of both ceroid and iron; imparting a pronounced golden brown colour in the haematoxylin eosin stained sections with the macrophages staining strongly for iron with Perl's Prussian blue stain. Melanomacrophages in the spleen and kidneys of these fish were replete with ceroid and the splenic macrophages carried large amounts of haemosiderin. Iron was also observed in the macrophages of the kidney but to a lesser extent than in the spleen and liver. Positive Perl's staining material was observed in some of the renal tubular epithelial cells. Sections of the ovaries of these fish showed numerous adventitious macrophage aggregates containing large amounts of iron, whereas testicular macrophage centres were devoid of iron. Macrophage aggregations associated with fat cell necrosis in the adipose tissues did not contain iron neither did the macrophages in the hypodermis or the macrophage centres in the pancreas.

Foci of inflammatory cells were observed in the heart, kidney and liver. In the liver these were associated with ducts and blood vessels. In the cranial and caudal kidney they appeared as focally disseminated clusters of dense basophilic cells. Wellencapsulated parasitic granulomata of varying sizes were a common finding in many of the livers. Secondary haemopoietic cell activity was prevalent in the heart and liver of many of the C. gariepinus specimens from the Gorge. Some of these specimens 
showed signs of excessive haemolysis, and an increase in the phagocytic lining of the ventricle. Pancreatic acinar and islet cells appeared normal in all of the fish although the prominence of pancreatic tissues, macroscopically, was quite variable.

Gills of many C. gariepinus specimens collected from the Olifants Gorge and lower Letaba River appeared paler than normal and mildly hyperplastic. Some of these gills, particularly in the C. gariepinus specimens from the gorge and lower Letaba River collected during January 2009, presented with a two to three-fold increase in the thickness of the epithelium of the secondary lamellae. In many of these specimens the epithelial hyperplasia increased towards the base of the secondary lamellae imparting a wedge shaped appearance. These changes were less evident in fish sampled from the same site in November 2009.

Examination of blood smears revealed an abundance of immature erythrocytes in many of the fish collected from the Gorge particularly during the January 2009 sampling. Many erythrocytes showed irregular shapes. Nuclear shapes were similarly irregular with a high prevalence of chromatin clumping visible within the nuclei.

Stomach contents from C. gariepinus specimens collected in the gorge near the confluence yielded mainly fish remnants, in many cases from fairly large fish. Specimens collected from waters directly over the silt deposits in the gorge on the Mozambique border appeared to have been ingesting only detritus and silt. This area was characterized by a general paucity of other fish species. 
A variety of parasites including monogenean trematodes and the cysts of digenetic trematode larvae were found in low to moderate numbers on the gills of many of the C. gariepinus specimens. Argulus japonicus parasites were found in low numbers on the gills of two $C$. gariepinus specimens. Various parasitic cysts were found in the mesenteric tissues, livers, serosa of the intestines and in the musculature of many of these fish. The peritoneal cavity of many of the $C$. gariepinus specimens yielded low to moderate numbers of nematodes. No difference in the pattern of parasitism between sampling sites could be detected, however it was note worthy that no protozoan parasites were observed.

\section{Discussion:}

Clarias gariepinus was the only fish species found in the Olifants Gorge to show significant lesions in the adipose tissues. Histological examination of the adipose tissues confirmed the presence of steatitis. The presence of ceroid laden macrophages and characteristic foreign body giant cells surrounding degenerating and ruptured adipocytes as well as the associated granuloma formation are typical findings in all species suffering from pansteatitis and microscopically the lesions in C. gariepinus resembled those described in other species (Begg et al. 2000; Goodwin 2006; Herman \& Kircheis 1985; Murai \& Andrews 1974; Roberts et al. 1979; Roberts \& Agius 2008). The macroscopic appearance of the adipose tissues of $C$. gariepinus differed from most other freshwater fish species that have characteristically white fat. A variation in colour from white through various shades of cream and yellow to dark orange appears to be normal in wild $C$. gariepinus. In contrast to pansteatitis in crocodiles and mammalian species, where affected fat tissue takes on a characteristic yellow colour, fat colour alone may be misleading when looking for signs of 
pansteatitis in C. gariepinus. Although fat consistency did change with steatitis in $C$. gariepinus, it did not take on the typically hard consistency noted in crocodiles (Larsen et al. 1983; Osthoff, Hugo, Bouwman, Bus, Govender, Joubert \& Swarts 2010).

The livers of $C$. gariepinus specimens caught in the gorge were characteristically fatty and showed signs of fatty degeneration of the hepatocytes with accumulation of both ceroid and haemosiderin in hepatocytes and melanomacrophages. Melanomacrophage centres are known to store lipofuscin, a breakdown product of unsaturated fatty acid peroxidation, as well as melanin and haemosiderin (Kennedy-Stoskopf 1993) and represent possible forerunners of the germinal centres in the spleen and lymphnodes of higher animals (Agius 1979). They are a unique feature of the lymphomyeloid tissue of fish (Kennedy-Stoskopf 1993) and play a role in iron storage (Agius 1979). Perl's Prussian blue stain demonstrates presence of ferric iron. Agius (1979) looked at the pattern of iron storage in the melanomacrophage centres in various organs of 14 different species of healthy and diseased fish. The spleen was the main organ of iron storage by melanomacrophages, whereas melanomacrophage centres in the liver and kidney were found to store insignificant amounts of iron. Whilst certain diseases including pansteatitis resulted in accumulation of iron in splenic macrophage centres, the same did not happen in hepatic and renal macrophage centres (Agius 1979). In $C$. gariepinus specimens from the gorge it was noted that the splenic melanomacrophages carried heavy deposits of iron. In the majority of fish this was also the case in the hepatic melanomacrophage centres and even renal melanomacrophages contained obvious amounts of iron, albeit less than in the liver. Adventitious macrophage aggregations in the ovaries also contained large amounts of 
iron where as macrophage aggregations associated with fat cell necrosis in the adipose tissues, and macrophage centres in the pancreas, testes and hypodermis did not contain iron. It is not clear whether the iron deposits represent increased iron storage as haemosiderin due to excessive haemolysis or whether they are indicative of abnormal uptake of iron from the environment. However, Baker, Martin \& Davies (1997) have demonstrated heightened oxidative stress in C. gariepinus ingesting increased levels of iron under experimental conditions.

The erythrocyte changes observed in blood smears from C. gariepinus in the Gorge showed the irregularity in shape described by Post (1993) and Murai \& Andrews (1974) in cases of vitamin E deficiency in fish. The observed nuclear and cell membrane abnormalities in the blood smears may point towards an increase in apoptosis. Reduced haemopoiesis in the kidney as well as an increase in erythrocyte turnover may explain the secondary haemopoiesis observed in the heart and liver in $C$. gariepinus from the Gorge.

Lesions associated with steatitis, other than those observed in the adipose tissues, appear to be variable depending on species involved. Exudative diathesis as described by Murai \& Andrews (1974) in channel catfish Ictalurus punctatus (Rafinesque) and muscular dystrophy described in channel catfish (Murai \& Andrews 1974) and rainbow trout Salmo gairdneri Richardson (Roberts et al. 1979) were not a consistent feature of the pansteatitis observed in C. gariepinus although an exudative peritonitis was noted in one fish suffering from steatitis. Fin loss and skin ulceration described in channel catfish in association with steatitis by Goodwin (2006) was not observed in $C$. gariepinus nor was a granulomatous infiltration between the pterygophores as 
described in wild common dab, Limanda limanda (L.) by Begg et al. (2000). The swimbladder changes described by Roberts et al. (1979) in rainbow trout suffering from pansteatitis could not be demonstrated in C. gariepinus, which has a reduced, displaced swimbladder enveloped by a bony capsule formed by the lateral processes of the fourth and fifth vertebrae (Petrick 1975). Roberts \& Agius (2008) described lethargy and erratic swimming bursts as presenting signs in farmed northern bluefin tuna Thunnus thynnus (L.) suffering from pansteatitis. No specific pathological changes were observed in the brain tissues of $C$. gariepinus specimens from the Olifants Gorge, but symptoms of lethargy and frenzied swimming would rapidly attract crocodiles making it unlikely that such advanced cases would be represented amongst the sampled fish.

There are few references in the literature describing pansteatitis in wild-caught freshwater fish. The condition has been described in various species of farmed fish where it is primarily a nutritional problem involving feeding of unsuitable quantities or types of unsaturated fats (Briknell, Bruno, Bowden \& Smith 1996; Goodwin 2006; Roberts \& Agius 2008) and where the condition can be mediated by presence of adequate vitamin E or addition of ethoxyquin in the diet (Murai \& Andrews1974). Begg et al. (2000) reported steatitis in two species of wild marine fish, common dab and long rough dab Hippoglossoides platessoides (Fabricius) with suspicion of a pollutionrelated aetiology. Bainy, Saito, Carvalho \& Junqueira (1996) have linked the effects of oxidative stress from polluted water to changes in antioxidant parameters in Nile tilapia Oreochromis niloticus. The initiation of lipid peroxidation by cyclic reductionoxidation has been linked to ingested iron (Minotti \& Aust 1992; Elbaraasi, Mézes, Balogh, Horváth \& Csengeri 2004) and the iron fraction in expandable clay minerals 
(Kibanova, Nieto-Camacho \& Cervini-Silva 2009). That C. gariepinus must have considerable anti-oxidant protective mechanisms is evidenced by their survival despite extensive lesions. It is noteworthy that lesions appeared to be restricted to the mesenteric fat, possibly indicating differing susceptibility of the various adipose reserves. Goodwin (2006) similarly found differences in susceptibility of various fat tissues in channel catfish suffering from steatitis. In the case of channel catfish the peritoneal fat reserves appeared to remain intact whereas lesions were found in the fin bases, the hypodermis and in the fat surrounding the brain. This may reflect differences in lipid type stored in the different fat tissues as proposed by Goodwin (2006). Some fat reserves may be more critical to the survival of wild fish reducing the likelihood of fish with extensive pansteatitis surviving to be caught on hook and line. For the same reason it is possible that some changes observed in other species of fish under aquaculture conditions would rarely be seen in wild caught specimens. In the Olifants River gorge high predator pressure would rapidly remove weakened fish.

Stomach and intestinal content of the steatitis affected $C$. gariepinus specimens indicated that appetite was not completely suppressed. This was confirmed by the willingness of the fish to take baited hooks. Similarly, in bluefin tuna suffering from pansteatitis, Roberts \& Agius (2008) found that the stomachs and intestines of even moribund fish contained food. C. gariepinus is an omnivorous benthic scavenger that is also known to actively hunt other fish (Bruton 1996). Significant differences in stomach and intestinal content were noted between the various sampling sites. Of significance was the presence of clay containing sediment in the intestines of fish caught in waters overlying the clay rich silt deposits in the gorge as well as the presence of fish remnants in the stomachs of specimens caught near the Olifants and 
Letaba confluence, at the entrance to the gorge. This was in contrast to the predominantly vegetable and invertebrate content found in the gastro-intestinal tracts of specimens caught at other sampling sites where steatitis did not occur. In the Olifants Gorge $C$. gariepinus reach a body mass of $9 \mathrm{~kg}$ and more. Remnants from often quite large fish were found in the stomach contents of these specimens, confirming that they were either preying on other weakened fish or scavenging off dead fish in the gorge.

The presence of diverse parasites at mild to moderate numbers reflected a relatively healthy host parasite relationship in the fish. The majority of the parasites noted have a multi-host lifecycle indicating that both the invertebrate intermediate host and the vertebrate final host must be present within the broader ecosystem.

C. gariepinus has a broad distribution and is ubiquitous in South African river systems and is hence worthy of investigation where anthropogenic activity has seriously impacted aquatic ecosystems. The variation in pathology that was observed in the fish from the Olifants Gorge appears consistent with oxidative stress. The most significant lesion identified during this fish health assessment was the steatitis present in the adipose tissues of $C$. gariepinus specimens from the Olifants Gorge. Poikilothermic (cold blooded) animals, such as fish, depend on lipoprotein polyunsaturated fats in order to maintain membrane fluidity and normal metabolic function especially at colder ambient temperatures (Stewart 1993). They are thus likely to be more sensitive to the effects of lipid autoxidation than warm-blooded animals. This may explain the observed mortalities in both crocodiles and sharptooth 
catfish during the winter months and the absence of mortality during the summer months.

\section{Conclusion}

It is unusual for a benthic, scavenger such as $C$. gariepinus to develop steatitis in the wild. This is the first record of steatitis in wild $C$. gariepinus as far as the authors are aware. This species of fish is hardy and well adapted to a wide habitat and food range explaining its extensive distribution throughout Africa. We conclude that it is unlikely that steatitis observed in the sharptooth catfish in the Olifants River is pure coincidence and propose that the finding is significant in relation to the development of pansteatitis in crocodiles occupying the same section of river.

\section{Acknowledgments}

The assistance received by Ampath Pathologists Laboratory who kindly prepared many of the histological tissue sections is gratefully acknowledged. We would also like to thank the SAN Parks staff that facilitated the fieldwork and the fishermen who assisted with catching fish. From the Department of Paraclinical Science at the Faculty of Veterinary Science, University of Pretoria, Dr. Johan Steyl is thanked for preparation of specially stained histology sections and Prof. John Lawrence for his editorial comments. Dr. Philippa Colly, of Sterkspruit Veterinary Clinic, is thanked for assistance with editing. The colleagues from the clinic are thanked for helping with dissections and standing in during the principle author's absence doing fieldwork. 


\section{References}

Agius C. (1979) The role of melano-macrophage centres in iron storage in normal and diseased fish. Journal of Fish Diseases 2, 337-343.

Bainy A.C.D., Saito E., Carvalho P.S.M. \& Junqueira V.B.C. (1996) Oxidative stress in gill, erythrocytes, liver and kidney of Nile tilapia (Oreochromis niloticus) from a polluted site. Aquatic Toxicology 34,151-162.

Baker R.T.M., Martin P. \& Davies S.J. (1997) Ingestion of sub-lethal levels of iron sulphate by African catfish affects growth and tissue lipid peroxidation. Aquatic Toxicology 40, 51-61.

Begg G.S., Bruno D.W. \& McVicar A.H. (2000) The histopathology and ultrastructure of steatitis affecting common dab Limanda limanda. Diseases of Aquatic Organisms 41 123-133.

Briknell I.R., Bruno D.W., Bowden T.J. \& Smith P. (1996) Fat cell necrosis syndrome in Atlantic halibut, Hippoglossus hippoglossus L. Aquaculture 144, 65-69.

Bruton M.N. (1996) Alternative life-history strategies of catfishes. In: The Biology and Culture of Catfishes. (ed. by M. Legendre, J-P. Proteau), Aquatic Living Resource 9, Hors série, 35-41.

De Villiers S. \& Mkwelo S.T. (2009) Has monitoring failed the Olifants River, Mpumalanga? Water SA 35, 671-676. 
Elbaraasi H., Mézes M., Balogh K., Horváth L. \& Csengeri I. (2004) Effects of dietary ascorbic acid/iron ratio on some production traits, lipid peroxide state and amount/activity of glutathione redox system in African catfish Clarias gariepinus (Burchell) fingerlings. Aquaculture research 35, 256-262.

Fytianou A., Koutinas A.F., Saridomichelakis M.N. \& Koutinas C.K. (2006) Blood $\alpha-$ tocopherol, selenium, and glutathione peroxidase changes and adipose tissue fatty acid changes in kittens with experimental steatitis (yellow fat disease). A comparative study between the domestic shorthaired and siamese breed. Biological Trace Element Research 112, 131-143.

Goodwin A.E. (2006) Steatitis, fin loss and skin ulcers of channel catfish, Ictalurus punctatus (Rafinesque), fingerlings fed salmonid diets. Journal of Fish Diseases 29, 61-64.

Herman R.L. \& Kircheis F.W. (1985) Steatitis in Sunapee trout, Salvelinus alpinus oquassa Girard. Journal of Fish Diseases 8, 237-239.

Huchzermeyer F.W. (2003) Crocodiles. Biology, Husbandry and Diseases, pp. 337. CABI Publishing, Wallingford, Cambridge.

Kennedy-Stoskopf S. (1993) Immunology. In: Fish Medicine (ed. By M.K. Stoskopf), pp. 149-159. W.B. Saunders Company, Harcourt Brace Jovanovich, Inc., Philadelphia, London, Toronto, Montreal, Sydney, Tokyo. 
Kibanova D., Nieto-Camacho A. \& Cervini-Silva J. (2009) Lipid peroxidation induced by expandable clay minerals. Environmental Science and Technology 43, $7550-7555$.

Larsen R.E., Buergelt C., Cardeilhac P.T. \& Jacobson E.R. (1983) Steatitis and fat necrosis in captive alligators. Journal of the American Veterinary Medical Association 11, 1202-1204.

Minotti G. \& Aust S.D. (1992) Redox cycling of iron and lipid peroxidation. Lipids 27, 219-226.

Murai T. \& Andrews J.W. (1974) Interactions of dietary $\alpha$-tocopherol, oxidized menhaden oil and ethoxyquin on channel catfish (Ictalurus punctatus). Journal of Nutrition 104, 1416-1431.

Osthoff G., Hugo A., Bouwman H., Buss P., Govender D., Joubert C.C. \& Swarts J.C. (2010) Comparison of the lipid properties of captive, healthy wild, and pansteatitisaffected wild Nile crocodiles (Crocodylus niloticus). Comparative Biochemistry and Physiology, Part A 155, 64-69.

Petrick F.O. (1975) Anatomy of the swimbladders of seven families of Transvaal freshwater fishes. Journal of the Limnological Society of Southern Africa 1(1), 17-22.

Post G.W. (1993) Nutrition and nutritional diseases of salmonids. In: Fish Medicine (ed. by M.K. Stoskopf), pp. 343-358. W.B. Saunders Company, Harcourt Brace Jovanovich, Inc., Philadelphia, London, Toronto, Montreal, Sydney, Tokyo. 
Roberts R.J. \& Agius C. (2008) Pan-steatitis in farmed northern bluefin tuna, Thunnus thynnus (L.), in the eastern Adriatic. Journal of Fish Diseases 31, 83-88.

Roberts R.J., Richards R.H. \& Bullock A.M. (1979) Pansteatitis in rainbow trout Salmo gaidneri Richardson: a clinical and histological study. Journal of Fish Diseases 2, 85-92.

Stewart L.J. (1993) Nutrition of koi, carp, and goldfish. In: Fish Medicine (ed. by M.K. Stoskopf), pp. 461-470. W.B. Saunders Company, Harcourt Brace Jovanovich, Inc., Philadelphia, London, Toronto, Montreal, Sydney, Tokyo. 
Table 1. Prevalence of macroscopically detectable steatitis lesions in Clarias gariepinus from the Olifants and Letaba River sampling sites on various sampling occasions

\begin{tabular}{|c|c|c|c|}
\hline Date & Site & Fish with steatitis & $\begin{array}{l}\text { Total fish } \\
\text { sampled }\end{array}$ \\
\hline September 2008 & Gorge Letaba confluence & 1 & 8 \\
\hline September 2008 & Letaba Ludwich's hut & 0 & 4 \\
\hline September 2008 & Letaba Klipkoppies bridge & 0 & 1 \\
\hline September 2008 & Olifants Mamba weir & 0 & 1 \\
\hline January 2009 & Gorge Letaba confluence & 0 & 7 \\
\hline January 2009 & Letaba Klipkoppies bridge & 0 & 2 \\
\hline January 2009 & Olifants Ngotso & 0 & 9 \\
\hline January 2009 & Olifants Mamba weir & 0 & 4 \\
\hline June 2009 & Gorge Letaba confluence & 3 & 9 \\
\hline June 2009 & Gorge Letaba confluence & 3 & 4 \\
\hline June 2009 & Letaba Klipkoppies bridge & 0 & 5 \\
\hline June 2009 & Olifants Ngotso & 0 & 10 \\
\hline July 2009 & Gorge Letaba confluence & 6 & 6 \\
\hline August 2009 & Gorge Letaba confluence & 1 & 2 \\
\hline August 2009 & Gorge Mozambique border & 4 & 12 \\
\hline November 2009 & Gorge Letaba confluence & 6 & 21 \\
\hline
\end{tabular}




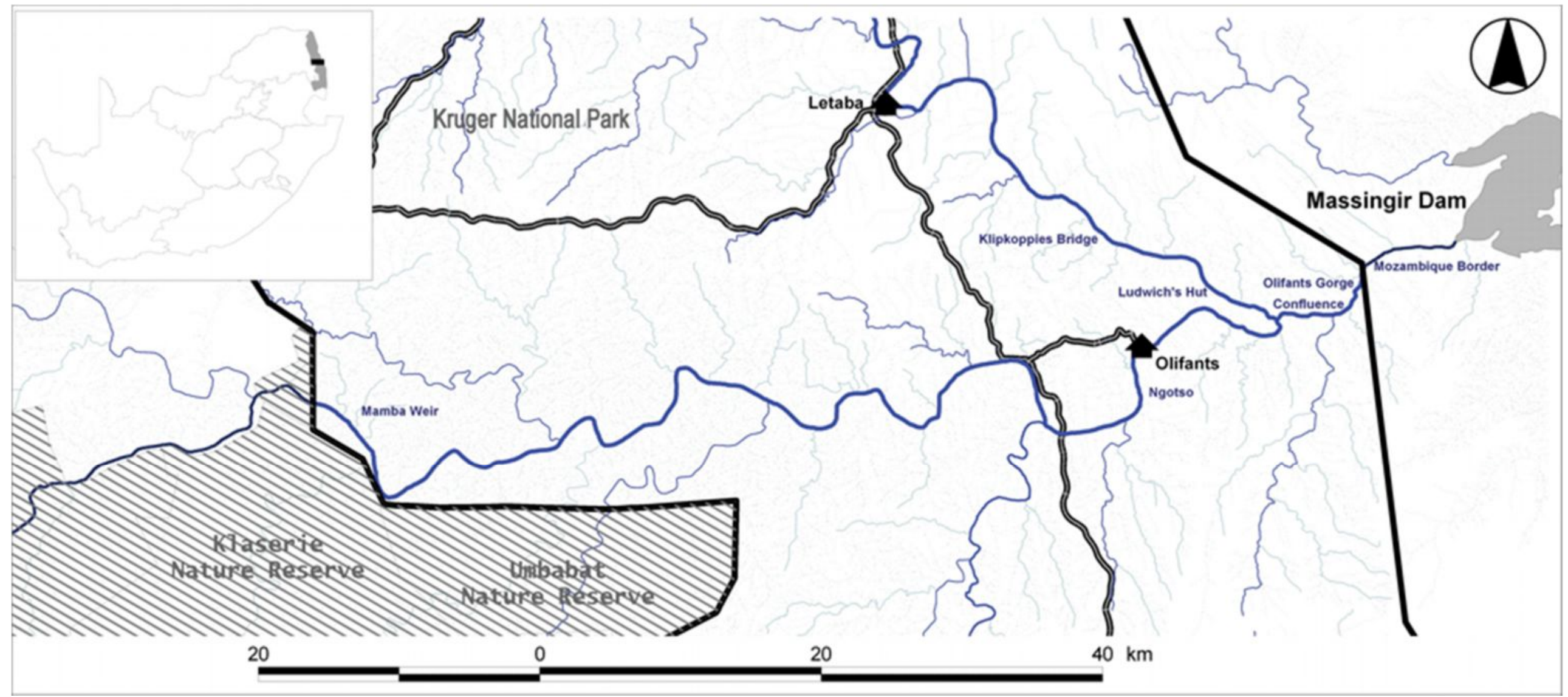

Figure 1. Sampling sites along the Olifants and Letaba rivers in the Kruger National Park, South Africa. 

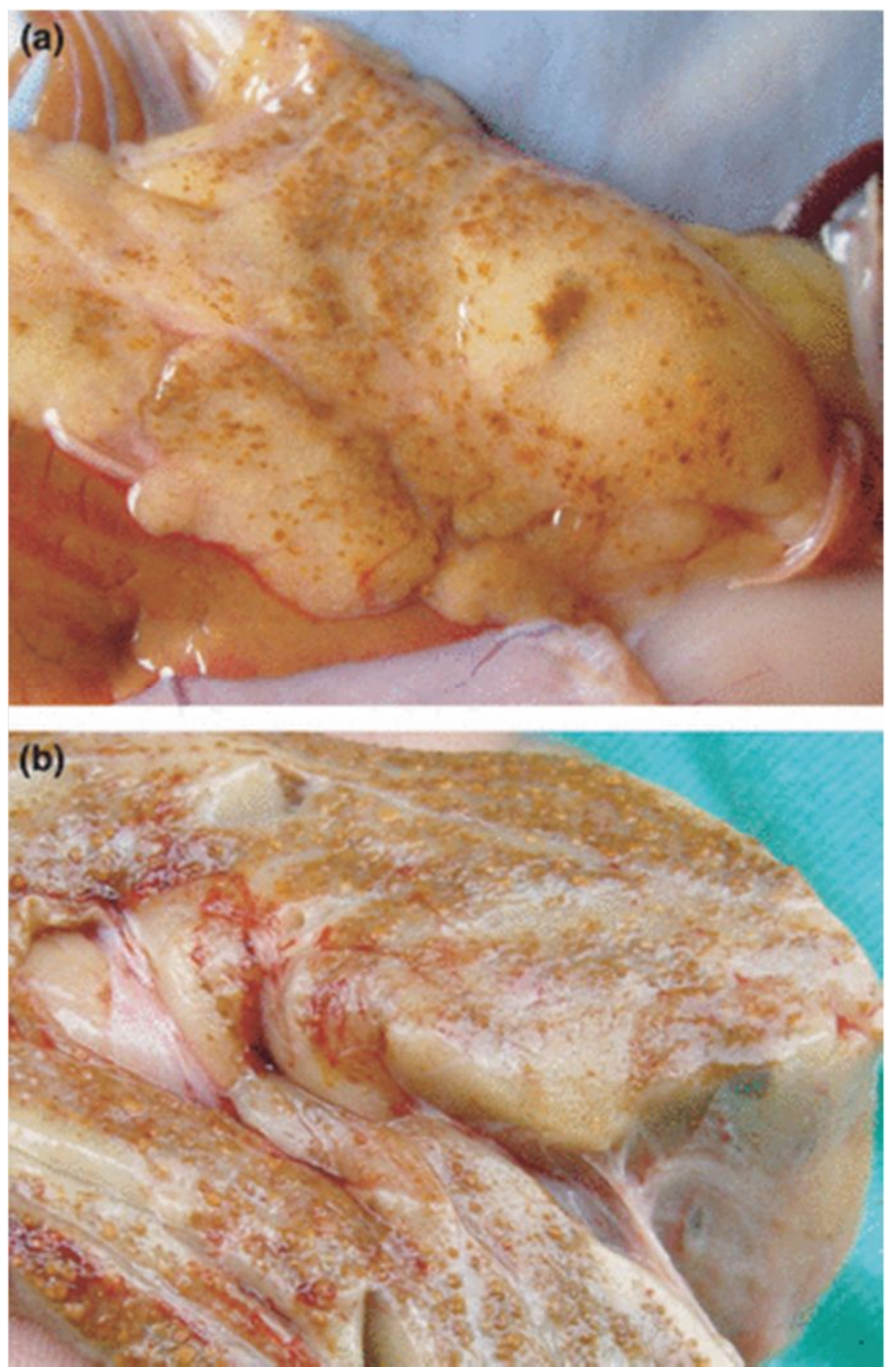

Figure 2. Macroscopic appearance of mesenteric adipose tissue from steatitis affected Clarias gariepinus from the Olifants Gorge. (a) Small golden brown granulomata from a mildly affected fish. (b) Advanced lesions from a severely affected fish. 

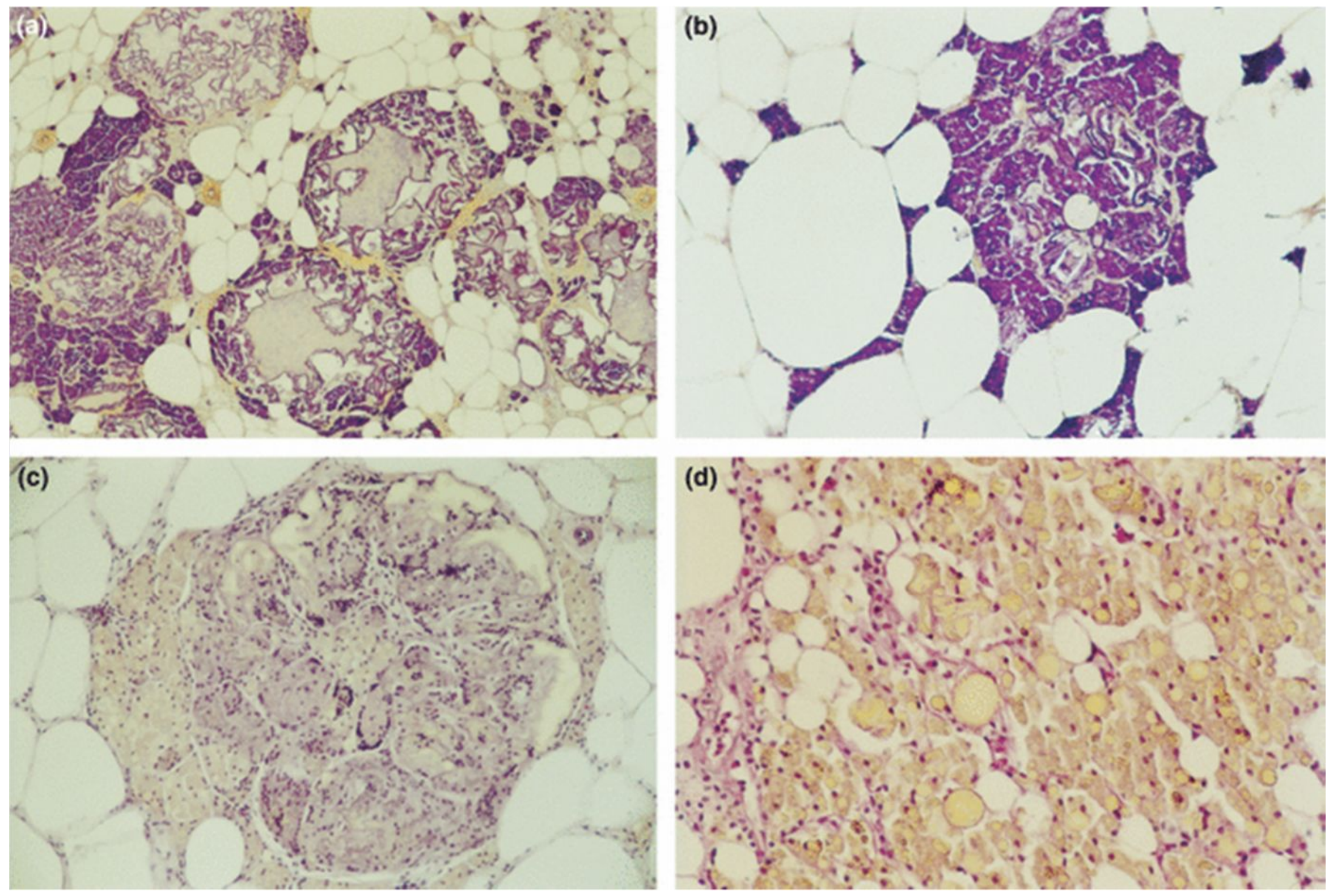

Figure 3. Histological sections of granulomata in the mesenteric fat of Clarias gariepinus from the Olifants Gorge. (a) Central area of fat necrosis consisting of lipopigment surrounded by ceroid-containing macrophages and fibroblast reaction (GAF, $\times 40$ ). (b) Ruptured adipocytes surrounded by ceroid-containing macrophages $(\mathrm{GAF}, \times 100)$. (c) Multinucleate giant cells surrounding areas of fat cell necrosis and lipopigment $(\mathrm{H} \& \mathrm{E} \times 100)$. (d) Xyleneinsoluble lipopigment inclusions in macrophages surrounding necrotic fat cells (H\&E $\times 400)$. 

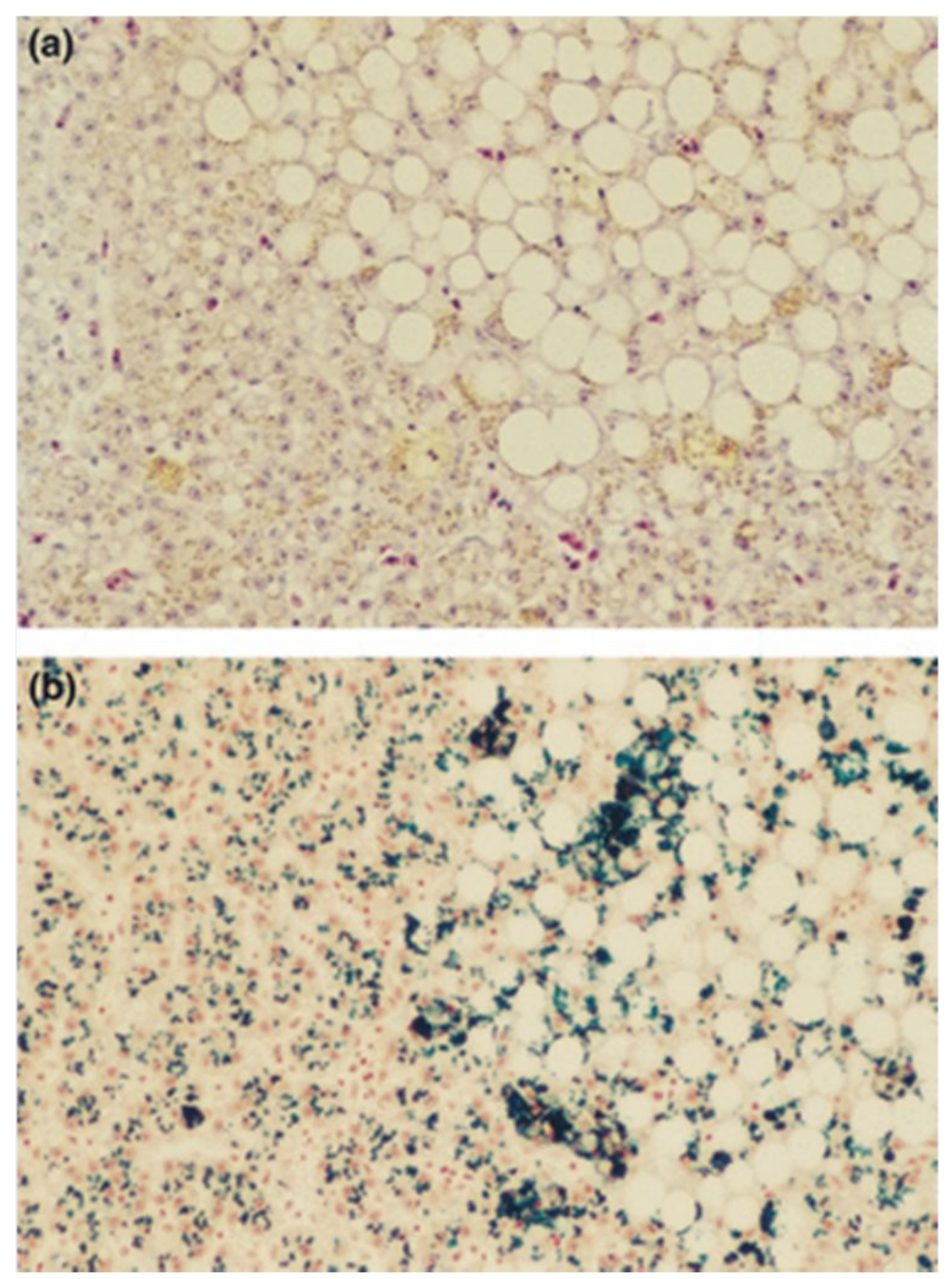

Figure 4. Histological section of liver of Clarias gariepinus from the Olifants Gorge. (a) Clearly demarcated zone of lipid vacuoles adjacent to nonvacuolated hepatocytes. Note pigment granules within macrophages and hepatocytes (H\&E, $\times 200)$. (b) Positive staining reaction for haemosiderin. Note irregular haemosiderin deposition within zone of lipid vacuolation (Perl's Prussian blue, $\times 200$ ). 